\title{
On the impact of temperature on tropospheric ozone concentration levels in urban environments
}

\author{
E Stathopoulou ${ }^{1}$, G Mihalakakou $^{2}$, M Santamouris ${ }^{1}$ and H S Bagiorgas ${ }^{2, *}$ \\ ${ }^{1}$ University of Athens, Department of Physics, Division of Applied Physics, Laboratory of Meteorology, \\ University Campus, Build. Phys. V, 15784 Athens, Greece. \\ ${ }^{2}$ University of Ioannina, Department of Environmental and Natural Resources Management, \\ 2 G. Sepheri Str., 30100 Agrinio, Greece. \\ *e-mail:chbagior@cc.uoi.gr
}

The influence of temperature on tropospheric ozone $\left(\mathrm{O}_{3}\right)$ concentrations in urban and photochemically polluted areas in the greater Athens region are investigated in the present study. Hourly values of the ambient air temperature used for studying the urban heat island effect in Athens were recorded at twenty-three experimental stations while ozone concentration values were measured at three of the above-mentioned stations and for a period of two years (1996-1997). The linear correlation between ozone concentration and air temperature values as well as the temporal variation of temperature and ozone concentration, for the above-mentioned experimental stations, were calculated and analysed. Moreover, a neural network approach was used for investigating the impact of temperature on the ozone concentration values over the greater Athens area. The neural network model used ambient air temperature as one of its input parameters and it was found that temperature is a predominant parameter, affecting considerably the ozone concentration values.

\section{Introduction}

Trace gases in the atmosphere (gases with concentrations below 1 ppmv) present a major impact on the environment, in spite of their relatively low concentrations. Some of these gases are toxic and can affect plant and animal life, while others can affect climate via the "atmospheric greenhouse effect" and the challenging task for scientists is to find out the factors that influence the presence of these trace gases.

Ozone has a major significance, as in stratosphere in the protection of the earth from the sun's harmful ultraviolet radiation so in troposphere in climate formation being a greenhouse gas and participating in the physicochemical processes (Crutzen 1998). Besides, ozone has strong oxidant properties, which may cause damage to humans, animals, vegetation and materials under conditions of increasing surface ozone concentration because of smog photochemical reactions in the presence of growing atmospheric pollution (nitrogen oxides, hydrocarbon compounds, etc.) (Güsten 1986; Kondratyev and Varotsos 2000; Bates 1994; Kalabokas et al 2000). Ozone exposure is especially associated with small increases in asthma morbidity and even mortality (Cody et al 1992; Kinney and Ozkaynak 1991; Kalabokas et al 2000), while the effects of ozone on plants may include visible leaf injury, reduced plant growth, decreased economic yield and changes in crop quality (USEPA 1986).

Tropospheric ozone originates from two sources, the intermittent engulfment of stratospheric ozone in the troposphere and the in situ formation from chemical processes among tropospheric trace gases, basically initiated by the reaction of $\mathrm{HO}_{2}+\mathrm{NO} \rightarrow$ $\mathrm{OH}+\mathrm{NO}_{2}$ (background chemistry), a subsequent

Keywords. Tropospheric ozone; urban environment; neural network models. 
photolysis of $\mathrm{NO}_{2}$ and a recombination with oxygen molecules (Fabian and Pruchniewicz 1977; Crutzen 1970; Chameides and Davis 1982; Hales 1996; Isaksen 1998; McKee 1994).

The importance of biomass burning in providing ozone precursors is great (Jacob et al 1999) as well as the long-range transport of ozone precursors (Fishman and Crutzen 1978; Liu et al 1980).

Investigation of northern hemisphere's tropospheric ozone influx (Grewe 2006, 2007) pointed out that for the Northern Hemisphere approximately $35 \%$ of the ozone influx originates from tropical stratospheric ozone on both hemispheres.

Both the aforementioned mechanisms are subject to temporal variability, e.g., the 11-year sun spot cycle significantly affects the stratospheric ozone introducing a variability of the ozone influx of approximately $\pm 1 \%$ (WMO 2003; Grewe 2006), in the tropical troposphere the $\mathrm{NO}_{x}$ and ozone concentration largely depends on the lightning produced $\mathrm{NO}_{x}$ (Lelieveld and Dentener 2000; Grewe 2004).

Considering the near surface ozone concentrations, these are mainly controlled by local and regional emissions (Grewe 2007), though they could also be affected by large scale transport, especially in winter.

In the last years there was a significant increase in tropospheric ozone concentration over the Northern Hemisphere due to an increase in anthropogenic ozone precursors (Bojkov 1986; Volz and Kley 1988; Staehelin et al 1994) which resulted in a higher photochemical activity of primary pollutants.

In central and northern Europe there have been many systematic measurements taken from urban and rural air pollution stations, providing a satisfactory picture of the spatial distribution of surface ozone concentrations (Kalabokas et al 2000).

On the contrary, in southern and eastern European countries and in countries near the Mediterranean basin such measurements have been focussed in and around the biggest cities, e.g., in Greece (Lalas et al 1987; Gusten et al 1988; Kalabokas et al 2000; Kouvarakis et al 2000; Glavas 1999; Ziomas 1998; Güsten et al 1997; Danalatos and Glavas 1996; Tsani-Bazaca et al 1988), in the countries of former Yugoslavia (Butković et al 1990; Klasinc and Cvita 1996), in Italy (Cieslik and Labatut 1997), in France (Pont and Fontan 2000a, b), in Spain (Sanz and Millán 1998; Zurita and Castro 1983), in Israel (Steinberger and Ganor 1980) and in Egypt (Güsten et al 1994; 1996). With the exception of the long-term background measurements of Kalabokas et al (2000) and Kouvarakis et al (2000) all other measurements were either sporadic for short periods of a few weeks only or in a polluted environment (Nolle 2001; Danalatos and Glavas 1996).

It is known that atmospheric ozone is highly variable and the trends derived in one location may not represent the whole region. Many factors exist simultaneously at different times or locations and the real system is much complicated. However, several studies suggest that climate impacts and especially temperatures are strong enough to affect the tropospheric ozone distribution (Hsu 2007; Valero et al 1992).

Temperature and long term urban warming have a serious impact on urban pollution, resulting in higher ozone concentrations, as heat accelerates the chemical reactions in the atmosphere (Clark and Karl 1982; Walcek and Yuan 1999). Higher ozone concentration values in urban environments are mainly caused by solar radiation and pollutants. Air temperature acts as a proxy parameter, representing the diurnal variation of solar radiation.

Urban areas accumulate greater amounts of heat than the surrounding rural country, resulting in higher air temperature values in densely populated and built areas. This phenomenon, which is widely known as the "heat island effect", is mainly caused by the differences in the thermal structure between urban and rural environments that are associated with thermal properties of urban materials, urban geometry, air pollution and the anthropogenic heat released by urban activities (Oke 1987; Mihalakakou et al 2004, Park 1986). The urban heat island phenomenon may occur during day or night-time periods and its patterns are strongly controlled by the unique characteristics of each urban area (Oke et al 1991). It is usually developed during clear, calm evenings and nights and is normally a result of delayed cooling of the city compared to surrounding rural areas (Barring et al 1985).

The city of Athens is characterised by a strong heat island effect, mainly caused by accelerated industrialization and urbanization during recent years. The effect appears during both summer and winter periods, with mean daily intensity ranging between 6 and $12^{\circ} \mathrm{C}$ for the major central area (Santamouris et al 1999). The Great Athens Area (GAA) includes about $40 \%$ of the Greek population, about $50 \%$ of Greek automobiles and $50 \%$ of the Greek industrial activities. That, in combination with the very large number of clear and sunny days, results in high concentrations of ozone, which usually exceed the U.S. Air Quality Standard of $120 \mathrm{ppb}$, especially during the summer months. Various researchers measured and analysed the ozone distribution in Athens (Lalas et al 1987; Gusten et al 1988). 


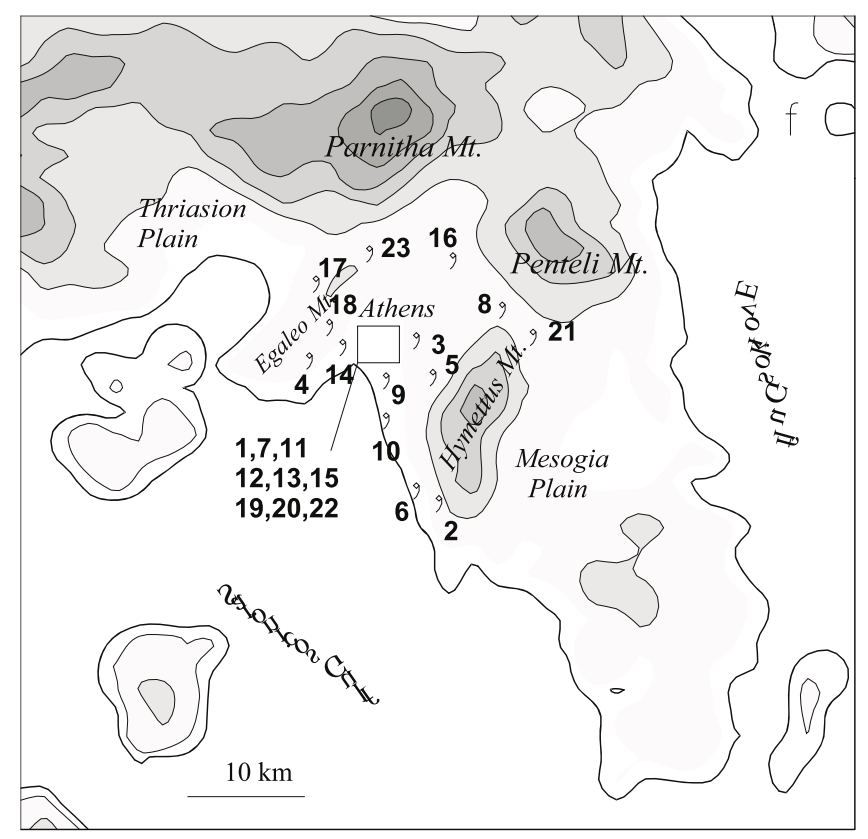

Figure 1. The Greater Athens areas with the 23 stations.

An intelligent method, such as the neural network systems, is designed in the present research for estimating the ozone concentration values in various urban locations. Artificial neural networks are computational systems, which are characterized by their capability of modeling complex nonlinear processes (Cichocki and Unbehauen 1993). They belong to the class of 'data-driven' approaches instead of 'model-driven' methods, because the analysis and results depend on the available data (Chakraborty et al 1992; Abdul-Wahab and Al-Alawi 2002).

The present paper aims at investigating the impact of temperature on the tropospheric ozone concentrations in three urban stations of GAA, where the urban heat island effect is significantly developed. Therefore, the daily evolution of the ozone concentration values has been correlated with the relative ambient air temperatures, while various neural network models were designed and used for giving quantitative information on the influence of temperature on ozone concentrations in urban environments.

\section{The experiment in GAA}

\subsection{Temperature measurements}

The GAA is located on a small peninsula in the southern edge of the Greek mainland. Hourly values of ambient air temperature and humidity were measured in 23 experimental stations installed in Athens urban and suburban regions for a period of 2 years, 1996-1997 (figure 1). The instrumentation used in the experiment was selected to satisfy several criteria such as acceptable cost, covering as many locations as possible, satisfactory performance according to international meteorological standards, low maintenance, internal power supply and high storage capacity. Miniature data loggers equipped with a thermistor were used for measuring hourly temperature values at each experimental location. The temperature sensors were calibrated and intercompared (accuracy of the sensors: $\pm 0.2^{\circ} \mathrm{C}$ ). The storage capacity of the data loggers allows operation for approximately 300 days, with a resolution of $0.5^{\circ} \mathrm{C}$. The instruments measuring air temperature values are installed in buildings at a height of around $5 \mathrm{~m}$, while south orientation is selected for all thermometers. A brief description of each experimental station is presented in table 1.

Seven stations were placed in the central area of Athens, fifteen in urban and suburban areas and in a radial configuration around the centre of Athens, while one station is placed in an almost rural region, at the foot of a mountain, in order to be used as the reference station.

\subsection{Ozone measurements}

Ozone concentrations were measured continuously at three of the above-mentioned stations, numbered 7, 8, and 14. Table 2 presents a brief description of the three experimental stations. $\mathrm{O}_{3}$ concentrations were monitored by ozone automatic analysers, operated on the principle of photometric detection of the specific absorption of UV light by ozone. Measurements were performed on a continuous daily basis and the automatic analysers' response time was $1 \mathrm{~min}$.

\section{Results and discussion}

\subsection{Experimental data analysis}

The influence of temperature on the ozone concentration values was examined, based on correlation coefficient and on temporal fluctuations, for the three above-mentioned experimental stations.

Figure 2 shows the linear correlations between ozone concentration and ambient air temperature values for the stations 14,7 and 8 , for the 2-year time period and for the hours 11:00 to 20:00 LST. Higher ozone concentration values in the urban environments are mainly caused by solar radiation and pollutants. Air temperature acts as a proxy parameter, representing the diurnal variation of solar radiation. For this reason, only diurnal variation of air temperature and ozone concentration values was used. 
Table 1. Characteristics of the experimental stations.

\begin{tabular}{|c|c|}
\hline $\begin{array}{l}\text { Station } \\
\text { number }\end{array}$ & Station characteristics \\
\hline 1 & $\begin{array}{l}\text { Placed on a green hill at the centre of Athens (altitude }=107 \mathrm{~m} \text { ). The area is charac- } \\
\text { terised by low building density and absence of traffic. }\end{array}$ \\
\hline 2 & $\begin{array}{l}\text { Placed in the south-eastern area of Athens near a mountain. The area is less populated } \\
\text { with low traffic and medium building density. }\end{array}$ \\
\hline 3 & $\begin{array}{l}\text { Placed in the eastern area of Athens centre. The area is densely populated with a lot } \\
\text { of traffic. }\end{array}$ \\
\hline 4 & $\begin{array}{l}\text { Placed in the south-western area of Athens. The area is less populated with low traffic } \\
\text { while its vegetation is nearly negligible. }\end{array}$ \\
\hline 5 & $\begin{array}{l}\text { Placed in the eastern area of Athens near a mountain. The area is highly populated } \\
\text { with a lot of traffic. }\end{array}$ \\
\hline 6 & $\begin{array}{l}\text { Placed in the southern coastal area of Athens, very close to the airport. The area is } \\
\text { characterised by very low traffic and by very few buildings. }\end{array}$ \\
\hline 7 & Placed in the centre of Athens. The area is densely populated with heavy traffic. \\
\hline 8 & $\begin{array}{l}\text { Placed in the north-eastern area of Athens between two mountains. The area is char- } \\
\text { acterised by an increased building's density and by heavy traffic. }\end{array}$ \\
\hline 9 & $\begin{array}{l}\text { Placed in the southern area of Athens centre in a big avenue. The area is highly } \\
\text { populated with heavy traffic. }\end{array}$ \\
\hline 10 & $\begin{array}{l}\text { Placed in the southern side of the previous avenue very close to the sea. The area is } \\
\text { characterised by low building's density and by heavy traffic. }\end{array}$ \\
\hline 11 & $\begin{array}{l}\text { Placed in the centre of Athens in a pedestrian road. The area is very densely built } \\
\text { and populated. }\end{array}$ \\
\hline 12 & $\begin{array}{l}\text { Placed in the centre of Athens. The area is characterised by a lot of traffic and by } \\
\text { very dense population. }\end{array}$ \\
\hline 13 & Placed in the centre of Athens. Traffic and buildings' density are very high. \\
\hline 14 & $\begin{array}{l}\text { Placed in the western area of Athens in a university campus characterised by a mod- } \\
\text { erate vegetation. }\end{array}$ \\
\hline 15 & Placed in the centre of Athens. The area is very densely populated with a lot of traffic. \\
\hline 16 & $\begin{array}{l}\text { Placed in the northern area of Athens. Traffic is very low and trees are scattered all } \\
\text { over the area. }\end{array}$ \\
\hline 17 & $\begin{array}{l}\text { Placed in the western limits of Athens basin in a foot-ball ground at the edge of a } \\
\text { planted area. The area is characterised by very low traffic and buildings' density. }\end{array}$ \\
\hline 18 & $\begin{array}{l}\text { Placed in the western area of Athens. Traffic is heavy while buildings' density is very } \\
\text { high. }\end{array}$ \\
\hline 19 & Placed in the city centre inside National Garden of Athens. \\
\hline 20 & $\begin{array}{l}\text { Placed in the Ancient Market of Athens. It is an area covered by bare soil and sur- } \\
\text { rounded by trees. }\end{array}$ \\
\hline 21 & $\begin{array}{l}\text { Placed in the north-eastern area of Athens in a suburb with increased traffic and } \\
\text { average vegetation. }\end{array}$ \\
\hline 22 & $\begin{array}{l}\text { Placed in the centre of Athens. The area is characterised by heavy traffic and large } \\
\text { green spaces which consist of gardens and trees. }\end{array}$ \\
\hline 23 & $\begin{array}{l}\text { Placed very near the centre of Athens in a big avenue. The area is not very densely } \\
\text { built with an average street vegetation but its traffic is high. }\end{array}$ \\
\hline
\end{tabular}

In the experimental station 14 , the ozone concentration values fluctuated between 4 and $297 \mathrm{ppb}$, while the $11.6 \%$ of ozone values are higher than the limit of $120 \mathrm{ppb}$. The high ozone concentration levels can be attributed to the area increased industrial activities which result in the $\mathrm{NO}_{x}$ production, most of which is generated from fossil fuel combustion boilers. The temperature values varied in the range of 1.5 to $41.9^{\circ} \mathrm{C}$. The ozone concentration values correlated quite well with the temperature ones resulting in a correlation coefficient equal to 0.77 .

For the experimental station 7 , which is a representative urban station located at the centre of Athens, the correlation coefficient between ozone concentration and temperature values was found equal to 0.59 for the same time period as for station 14. The ozone values fluctuated between 4 and $157 \mathrm{ppb}$, while only $0.3 \%$ of them is higher than the air quality standard of $120 \mathrm{ppb}$. The 
Table 2. Characteristics of the three experimental stations, where temperature and ozone concentration values were measured.

\begin{tabular}{cl}
\hline $\begin{array}{c}\text { Station } \\
\text { number }\end{array}$ & \multicolumn{1}{c}{ Characteristics } \\
\hline 14 & $\begin{array}{l}\text { It is placed in the central-western area in } \\
\text { a university campus. Moderate vegetation, } \\
\text { light traffic, low building density but with } \\
\text { high industrial activities. }\end{array}$ \\
& $\begin{array}{l}\text { It is placed in a central area very densely } \\
\text { populated with heavy traffic. }\end{array}$ \\
8 & $\begin{array}{l}\text { It is placed in the northeastern area of } \\
\text { Athens. Increased building density and } \\
\text { heavy traffic. }\end{array}$ \\
\hline
\end{tabular}

majority of high concentrations in this station can be attributed to traffic. The relatively low values of ozone measured in the city center when compared with those measured in the suburbs should be noticed. This is mainly explained by the fact that $\mathrm{O}_{3}$ generated over the sea and advected over the city enhances the concentrations near the shoreline and far inland but lightly in the city center. The relative temperature variation was between 5.8 and $42.8^{\circ} \mathrm{C}$.

Finally, in the experimental station 8 the relative correlation coefficient was equal to 0.48 , while the ozone concentration values varied in the range of 6 to $315 \mathrm{ppb}$. $18.1 \%$ of these values are higher than the limit of $120 \mathrm{ppb}$. The high values of ozone at this station can be attributed to both locally produced ozone because of the traffic and transported ozone or transported $\mathrm{O}_{3}$ precursors $\left(\mathrm{NO}_{x}\right.$ and $\mathrm{HC}_{s}$ ). Sea breeze can play a significant role in pollutants' motion by bringing air masses from the sea over the center of the city and by advecting them northward (Gusten et al 1988). The temperature in that case fluctuated between 6.9 and $34.9^{\circ} \mathrm{C}$.

Furthermore, the temporal variation of both ozone concentration and temperature values was examined for the whole experimental period. Figure 3 shows the temporal variation of ozone concentration and temperature values for three randomly selected continual days of August 1996 (6th, 7th, and 8 th). As it can be seen, the ozone concentration fluctuation follows the relative temperature variation, especially during the daytime, when the highest values of ozone are observed because of the high values of solar radiation and of the high concentrations of ozone precursors $\left(\mathrm{NO}_{x}\right.$ and NMHC). As ozone concentration values are dependent directly on solar radiation, the ozone concentration values are much higher during the daytime and as air temperature is used in the present research as a proxy parameter, representing the diurnal variation of solar radiation, ozone concentration values
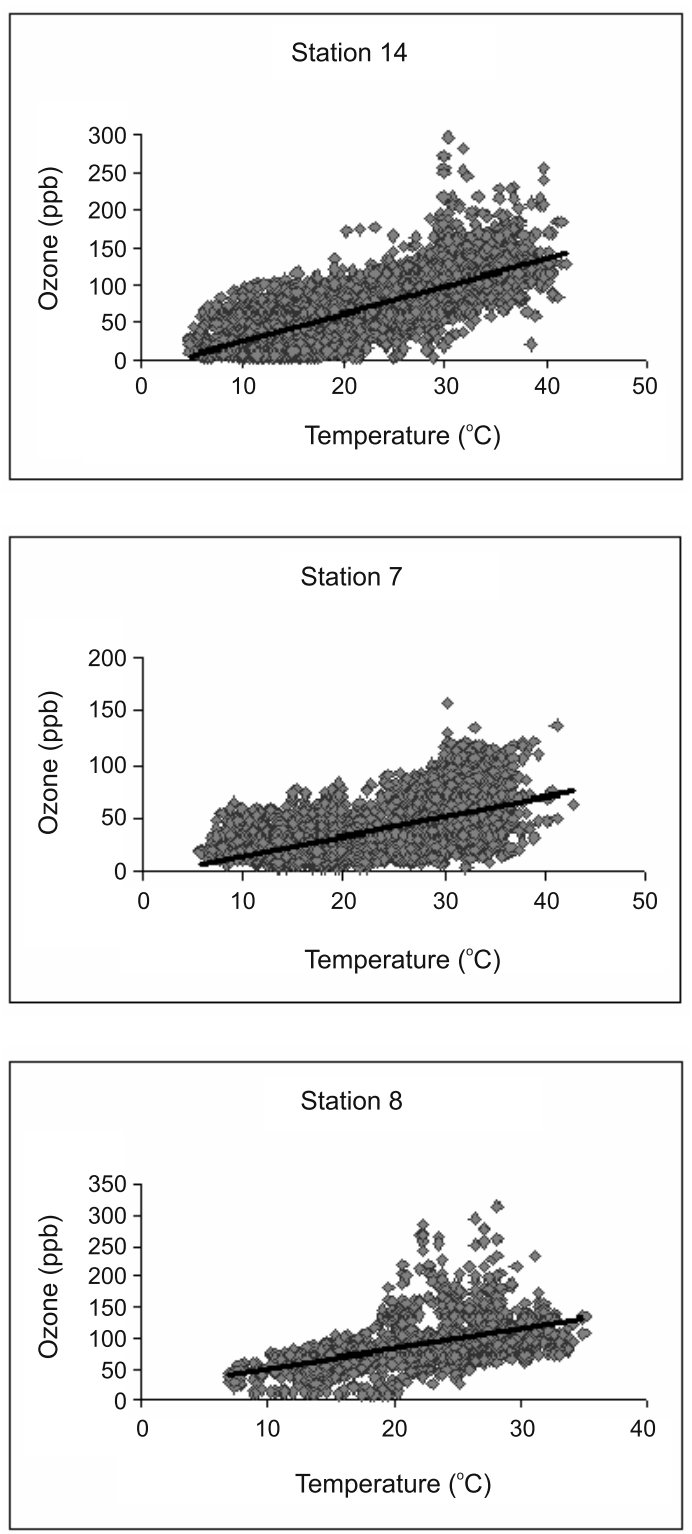

Figure 2. Linear correlations between ozone concentration values and the ambient air temperature ones for the three stations.

correlate much better with air temperature during sunlit hours. Analytically, correlation coefficient varied between 0.39 and 0.81 for sunlit hours and between 0.17 and 0.61 for non-sunlit hours, for the whole set of measurements.

\subsection{The neural network approach}

Artificial neural networks are computing systems which attempt to simulate the structure and function of biological neurons ( $\mathrm{Li}$ et al 1990) and therefore, are considered capable to model complex nonlinear processes (Chakraborty et al 1992). Neural networks generally consist of a number of interconnected processing elements or neurons. The way the inter-neuron connections are 

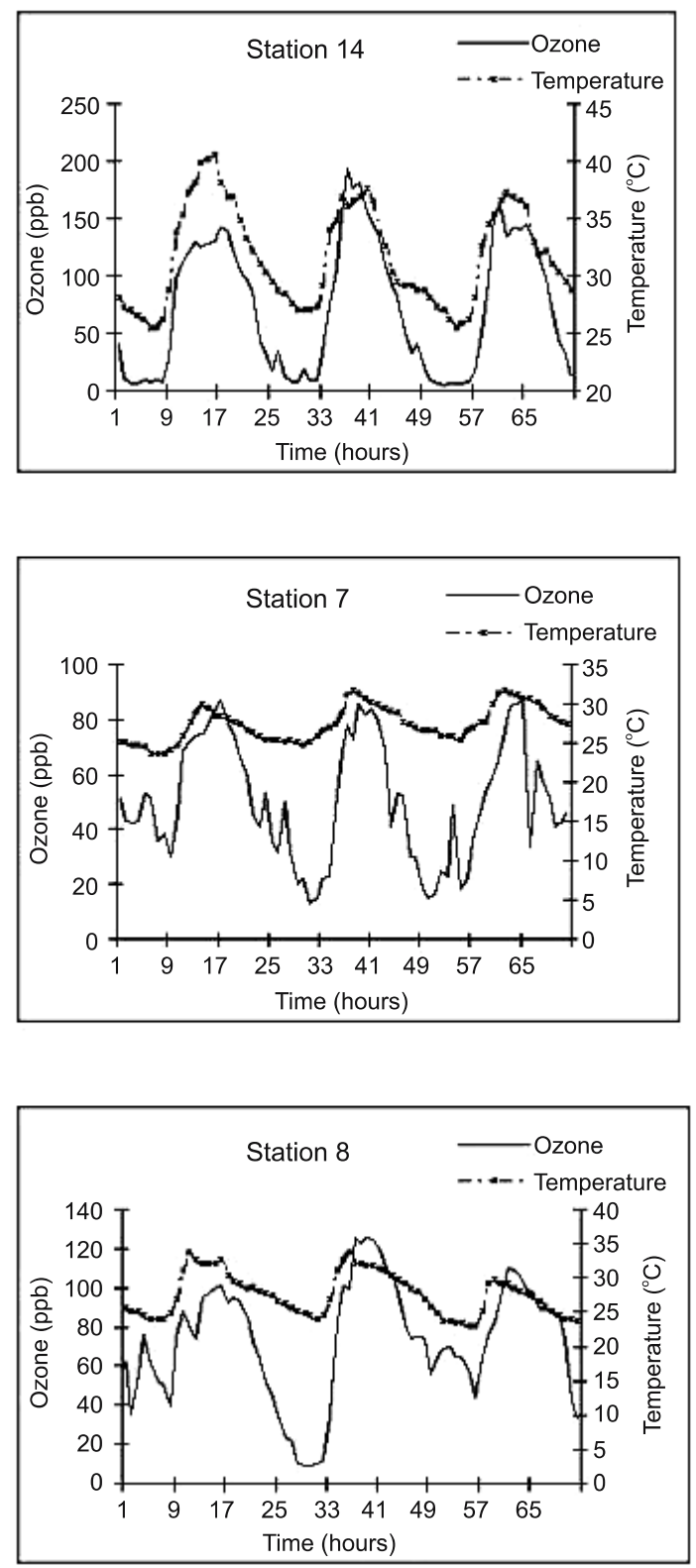

Figure 3. Temporal variation of ozone concentration and temperature values for the three stations and for three randomly selected continual days of August 1996 (6th, 7th, and 8th).

arranged and the nature of the connections determine the structure of a network. The estimation or prediction problem using neural networks can be separated into three steps: designing the neural models architecture, training the network and testing or diagnostic checking.

In the present study, a neural model was designed separately for each station. The model's architecture consisted of one hidden layer of 24-25 so-called tan-sigmoid neurons, followed by an output layer of one linear neuron. Learning was achieved using the back-propagation algorithm (Rumelhart et al 1986) to train the network. Mathematically, back-propagation is gradient descent
Table 3. Mean monthly values of $\mathrm{NO}$ and $\mathrm{NO}_{2}$ concentrations at the experimental station 14 for the years 1996-1997 $\left(\mu g / m^{3}\right)$.

\begin{tabular}{lccccc}
\hline & \multicolumn{3}{c}{ Station 14} & & \\
\cline { 6 - 6 } & 1996 & 1997 & & 1996 & 1997 \\
\cline { 2 - 3 } & 31 & 90 & & 37 & 63 \\
January & 49 & 54 & & 48 & 51 \\
February & 69 & 48 & & 52 & 43 \\
March & 51 & 25 & & 44 & 30 \\
April & 17 & & & 36 & \\
May & 25 & 20 & & 42 & 56 \\
June & 27 & 19 & & 47 & 49 \\
July & 36 & 12 & & 39 & 29 \\
August & 56 & 21 & & 30 & 45 \\
September & 31 & 57 & & 41 & 38 \\
October & 36 & 42 & & 43 & 32 \\
November & 98 & 79 & & 51 & 58 \\
December & 44 & 44 & & 43 & 46 \\
Mean & & & & & \\
\hline
\end{tabular}

of the mean-squared error as a function of the weights. Two of the main parameters of the backpropagation algorithm are the learning rate and the error goal. The learning rate specifies the size of changes that are made in the weights and biases at each epoch while the error goal is the desired sum-squared error. Various learning rates and error goals are tested during the training process in order to decrease the sum-squared errors and diminish the difference between the network's output and the target output. A learning rate of 0.1-0.4 and an error goal of 0.5 were selected, while the number of epochs varied between 3000 and 5000 in all cases.

The ozone concentration values at each station have been estimated by the neural network models using the following four input parameters for each station:

- ambient air temperature measurements in ${ }^{\circ} \mathrm{C}$

- measurements of $\mathrm{NO}$ concentrations in $\mathrm{ppb}$

- measurements of $\mathrm{NO}_{2}$ concentrations in ppb and

- time in hours.

Tables 3, 4 and 5 demonstrate mean monthly values of $\mathrm{NO}$ and $\mathrm{NO}_{2}$ concentrations for the three experimental stations and for the testing period.

The neural models were primarily trained using the dataset measurements and furthermore were tested using a randomly selected set consisting of $15 \%$ of the total measurements dataset. Figure 4 shows the comparison between the estimated ozone concentration values using the neural model and the measured ones for the selected stations and for the testing period. 
Table 4. Mean monthly values of $\mathrm{NO}$ and $\mathrm{NO}_{2}$ concentrations at the experimental station 7 for the years 1996-1997 $\left(\mu \mathrm{g} / \mathrm{m}^{3}\right)$.

\begin{tabular}{lrrrrr}
\hline & \multicolumn{3}{c}{ Station 7} & & \\
\cline { 2 - 3 } & 1996 & 1997 & & 1996 & 1997 \\
\cline { 2 - 3 } \cline { 5 - 6 } January & 112 & 208 & & 65 & 86 \\
February & 143 & 191 & & 80 & 102 \\
March & 109 & 106 & & 78 & 83 \\
April & 142 & 124 & & 113 & 97 \\
May & 149 & 119 & & 113 & 116 \\
June & 122 & 113 & & 110 & 117 \\
July & 100 & 89 & & 112 & 99 \\
August & 71 & 64 & & 95 & 80 \\
September & 137 & 99 & & 107 & 86 \\
October & 157 & 135 & & 93 & 96 \\
November & 217 & 167 & & 103 & 84 \\
December & 213 & 208 & & 81 & 86 \\
Mean & 139 & 135 & & 95 & 95 \\
\hline
\end{tabular}

Table 5. Mean monthly values of $\mathrm{NO}$ and $\mathrm{NO}_{2}$ concentrations at the experimental station 8 for the years 1996-1997 $\left(\mu \mathrm{g} / \mathrm{m}^{3}\right)$.

\begin{tabular}{lccccc}
\hline & \multicolumn{3}{c}{ Station 8} & & \\
\cline { 6 - 7 } & 1996 & 1997 & & 1996 & 1997 \\
\cline { 2 - 3 } \cline { 5 - 6 } January & 9 & 37 & & 23 & 47 \\
February & 17 & 32 & & 48 & 29 \\
March & 10 & 24 & & 23 & 28 \\
April & 18 & 27 & & 39 & 35 \\
May & 25 & & & 51 & \\
June & 21 & 12 & & 17 & 35 \\
July & 17 & 11 & & 21 & 43 \\
August & 16 & 20 & & 22 & 35 \\
September & 14 & & & 27 & \\
October & 17 & & & 17 & \\
November & 38 & & 38 & \\
December & 42 & & 33 & \\
Mean & 20 & 24 & 30 & 34 \\
\hline
\end{tabular}

As shown, there is a good agreement between estimated and measured values, while the correlation coefficients fluctuated between 0.89 and 0.94 . For the training set, in figure 5 it can be seen in the temporal variation of the estimated and measured ozone concentrations for three randomly selected continual days for the three stations.

Good agreement is observed between the estimated and measured data for the whole training set of measurements. In order to examine and give a more quantitative information on the
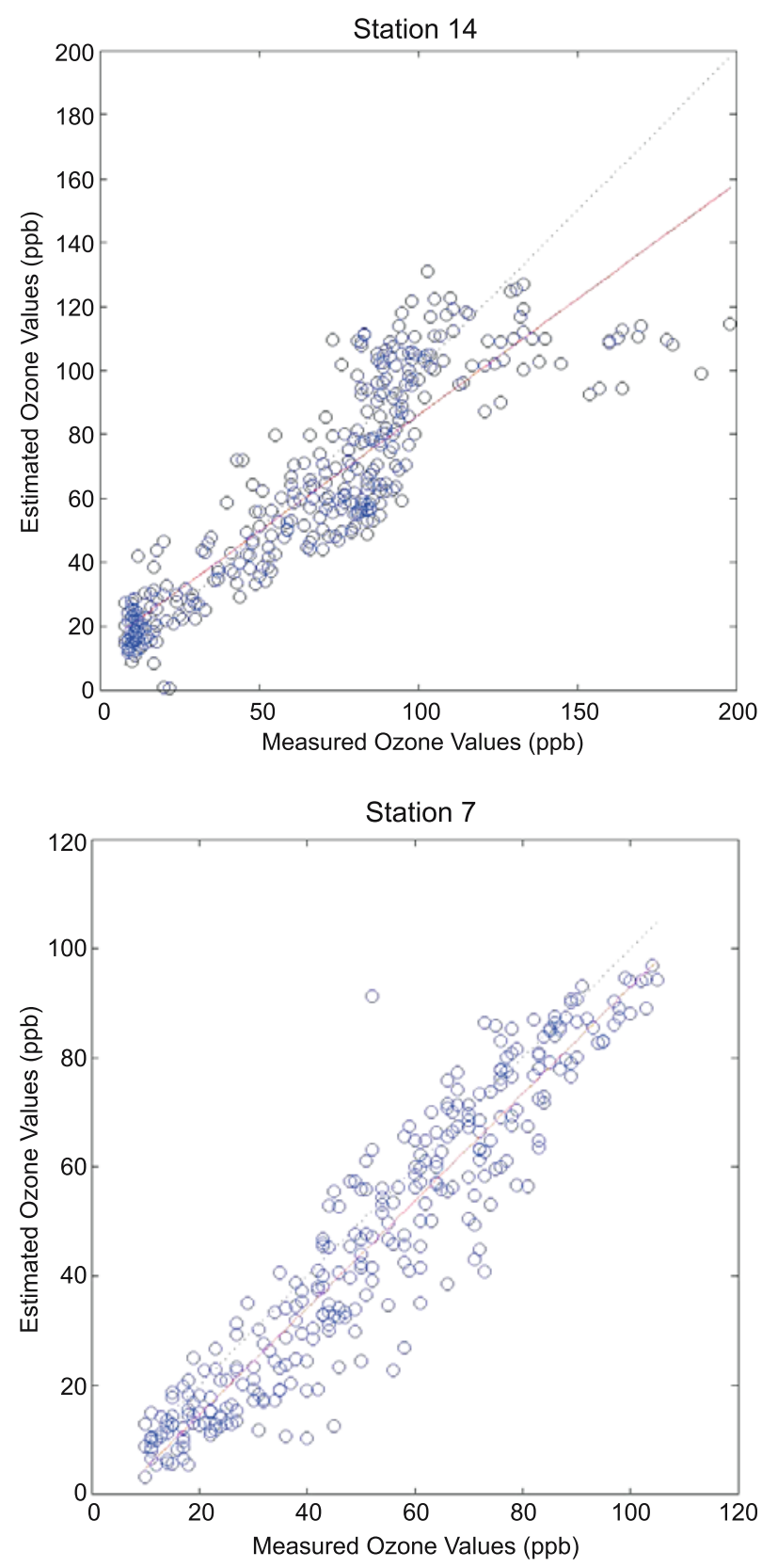

Figure 4. (Continued)

impact of ambient air temperature values on the ozone concentration ones, neural network models were designed for the estimation of ozone concentrations of each station, using as input parameter only the air temperature. Table 6 shows the correlation coefficients between measured and estimated ozone concentration values for each station and for the following cases: a. all four previously mentioned input parameters were used as inputs to the model $\left(\mathrm{R}_{1}\right)$ and b. ambient air temperature was used as the only input $\left(R_{2}\right)$. As shown, the correlation coefficient reduction fluctuated between 11.2 and $27.7 \%$. Thus, the neural models, by using the air temperature as the only 

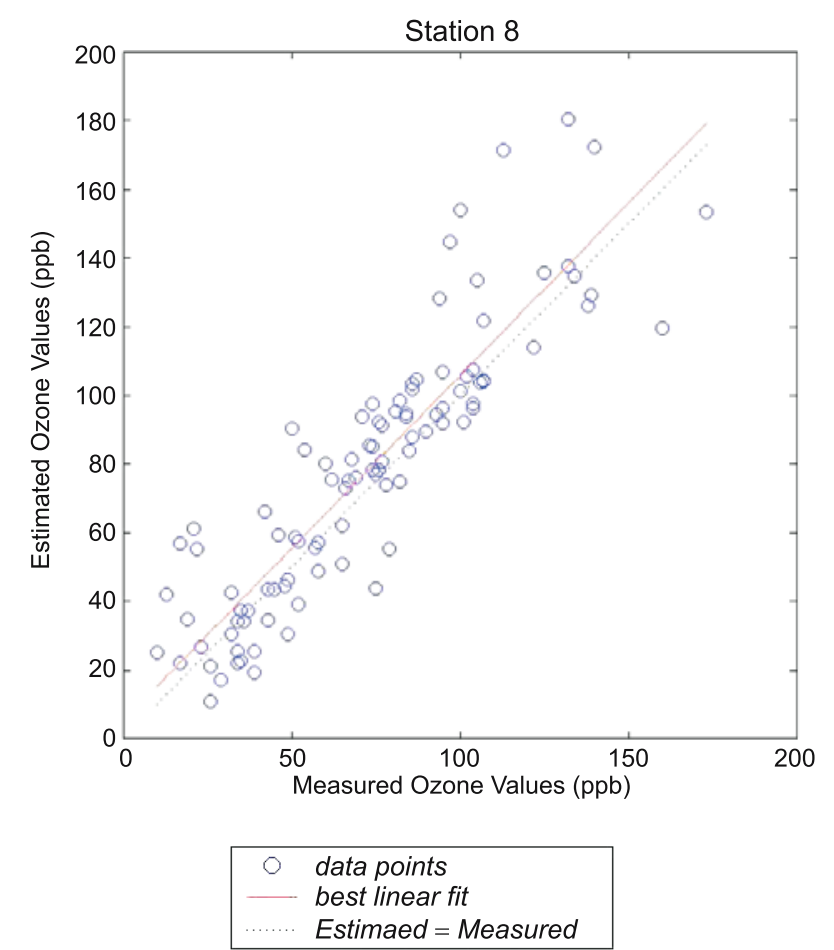

Figure 4. Comparison between the estimated ozone concentration values using the neural model and the measured ones for the three stations and for the testing period.

Table 6. Correlation coefficients between measured and estimated ozone concentrations, when all parameters are used as inputs $\left(R_{1}\right)$, and when air temperature is used as the only input parameter $\left(R_{2}\right)$.

\begin{tabular}{cccc}
\hline $\begin{array}{c}\text { Station } \\
\text { number }\end{array}$ & $\mathrm{R}_{1}$ & $\mathrm{R}_{2}$ & $\begin{array}{c}\text { Reduction } \\
(\%)\end{array}$ \\
\hline 14 & 0.89 & 0.79 & 11.2 \\
7 & 0.90 & 0.65 & 27.7 \\
8 & 0.92 & 0.72 & 21.7 \\
\hline
\end{tabular}

input parameter, can provide remarkably accurate estimations. This can be explained primarily by the fact that strong sunlight intensity, which is one of the most important factors affecting and enhancing photochemical ozone formation, is usually characterized by relatively high temperature values. Moreover, urban environments are mainly characterized by higher temperature values, caused by the anthropogenic heat released by cars and industrial activities, which simultaneously enhance the $\mathrm{O}_{3}$ formation. Of course, the estimations are improved with the addition of the ozone precursors' concentration values as input parameters. However, it is clear that ambient air temperature considerably affects the tropospheric ozone formation and development.
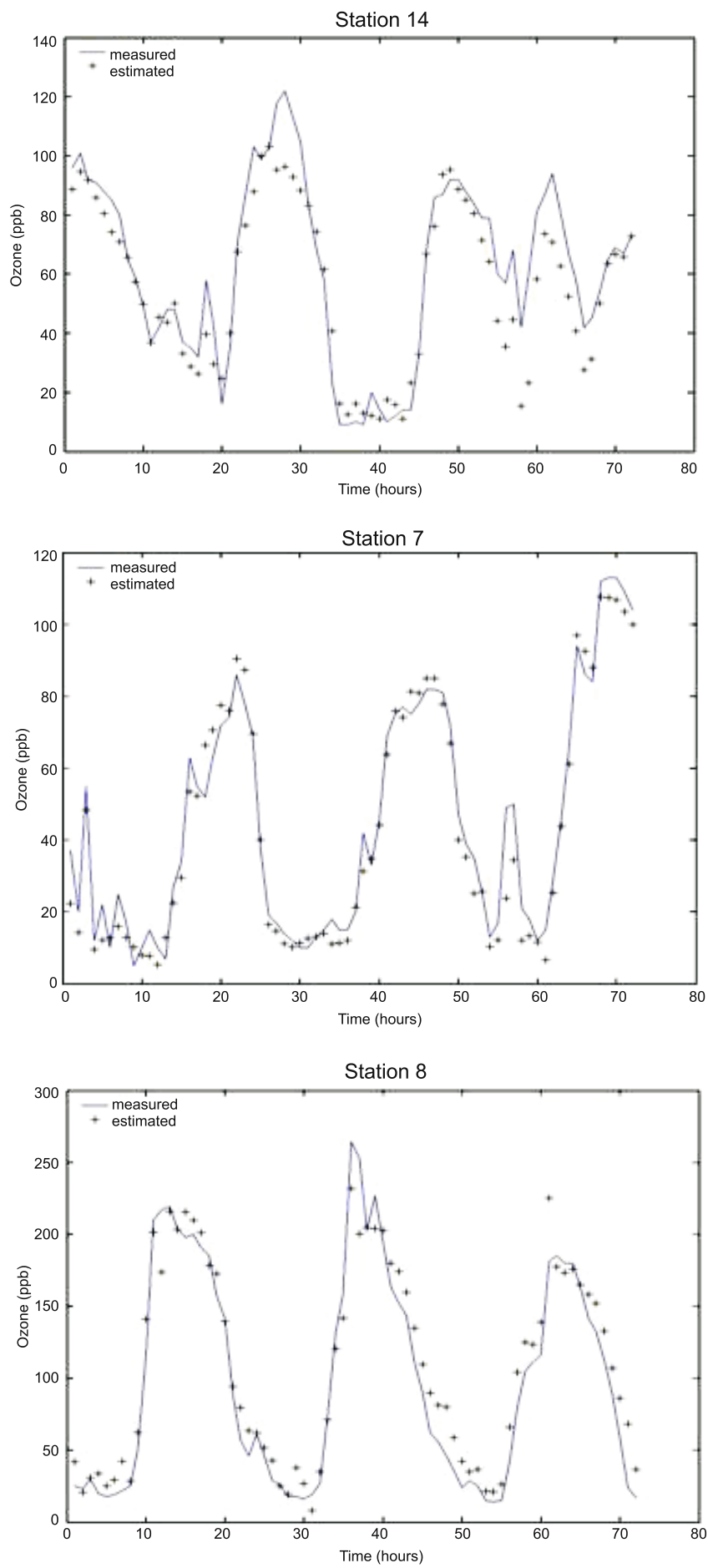

Figure 5. Temporal variation of the estimated and measured ozone concentrations for the three stations and for three randomly selected continual days of the training period.

\section{Concluding remarks}

The impact of temperature on the tropospheric ozone concentration levels in the urban area of Athens has been investigated in the present paper. For this reason, air temperature and ozone 
concentration data from several experimental stations in the greater Athens area were collected and used for performing linear correlations and temporal variation analysis. Furthermore, the analysis was enriched with a neural network method for achieving a more quantitative approach of the influence of temperature on the ozone concentration values over the greater Athens area. Ambient air temperature and $\mathrm{NO}_{x}$ concentration values were mainly used as input parameters to the neural network models. The results showed that temperature is a predominant parameter, affecting considerably the ozone concentration values.

\section{References}

Abdul-Wahab S A and Al-Alawi S M 2002 Assessment and prediction of tropospheric ozone concentration levels using artificial neural networks; Environ. Model. Softw. 17 219-228.

Barring L, Mattsso J O and Lindqvist S 1985 Canyon Geometry, street temperatures and urban heat island in Malmo, Sweden; J. Climatol. 5 433-444.

Bates D 1994 The effects of ozone on plants and people; In: Chemistry of the Atmosphere: Its Impact on Global Change (ed) J Calvert, (Oxford: Blackwell Scientific Publications) 239-244.

Bojkov R 1986 Surface ozone during the second half of the nineteenth century; J. Clim. Appl. Metereol. 25 343-352.

Butković V, Cvita T and Klasinc L 1990 Photochemical ozone in the Mediterranean; Sci. Total Environ. 99 $145-151$.

Chakraborty K, Mehrotra K, Mohan C K and Ranka S 1992 Forecasting the behavior of multivariate time series using neural networks; Neural Networks 5 961-970.

Chameides W L and Davis D D 1982 Chemistry in the troposphere; Chem. Eng. News $6038-52$.

Cichocki A and Unbehauen R 1993 Neural Networks for Optimisation and Signal Processing (Stuttgart: John Wiley \& Sons).

Cieslik S and Labatut A 1997 Ozone and heat fluxes over a Mediterranean pseudosteppe; Atmos. Environ. 31 $177-184$

Clark T L and Karl T R 1982 Application of prognostic meteorological variables to forecasts of daily maximum one-hour ozone concentrations in the northeastern United States; J. Appl. Meteorol. 21 1662-1671.

Cody R P, Weisel C P, Birnbaum G and Lioy P J 1992 The effect of ozone associated with summertime photochemical smog on the frequency of asthma visits to hospital emergency departments; Environ. Res. $\mathbf{5 8}$ 184-194.

Crutzen P J 1970 The influence of nitrogen oxides on the atmospheric ozone content; Q. J. Roy. Meteor. Soc. 96 $320-325$.

Crutzen P J 1998 How the atmosphere keeps itself clean and how this is affected by human activities?; Pure Appl. Chem. 70 1319-1326.

Danalatos D and Glavas S 1996 Diurnal and seasonal variations of surface ozone in a Mediterranean coastal site, Patras, Greece; Sci. Total Environ. 177 291-301.

Fabian P and Pruchniewicz P G 1977 Meridional distribution of ozone in the troposphere and its seasonal variation; J. Geophys. Res. 82 2063-2073.
Fishman J and Crutzen P 1978 The origin of ozone in the troposphere; Nature 274 855-858.

Glavas S 1999 Surface ozone and $\mathrm{NO}_{x}$ concentrations at a high altitude Mediterranean site, Greece; Atmos. Environ. 33 3813-3820.

Grewe V 2004 Technical note: a diagnostic for ozone contributions of various $\mathrm{NO}_{x}$ emissions in multi-decadal chemistry-climate model simulations; Atmos. Chem. Phys. Discuss. 4 729-736.

Grewe V 2006 The origin of ozone; Atmos. Chem. Phys. Discuss. 6 1495-1511.

Grewe V 2007 Impact of climate variability on tropospheric ozone; Sci. Total Environ. 374 167-181.

Güsten H 1986 Formation, transport and control of photochemical smog, In: The handbook of environmental chemistry, (ed.) O Hutzinger (Berlin, Germany: SpringerVerlag) Vol. 4/Part A - Air pollution, 53-106.

Güsten H, Heinrich G, Cvitas T, Klasinc L, Rus B, Lalas D P and Petrakis M 1988 Photochemical formation and transport of ozone in Athens, Greece; Atmos. Environ. 22 1855-1861.

Güsten H, Heinrich G, Weppner J, Abdel-Aal M M, Abdel-Hay F A, Ramadan A B, Tawfik F S, Ahmed D M, Hassan G K Y, Cvita T, Jeftić J and Klasinc L 1994 Ozone formation in the Greater Cairo Area; Sci. Total Environ. 155 285-295.

Güsten H, Heinrich G, Mönnich E, Sprung D, Weppner J, Ramadan A B, Ezz El-Din M R M, Ahmed D M and Hassan G K Y 1996 On-line measurements of ozone surface fluxes: Part II; Surface-level ozone fluxes onto the Sahara desert; Atmos. Environ. 30 911-918.

Güsten H, Heinrich G, Mönnich E, Weppner J, Cvita T, Klasinc L, Varotsos C A and Asimakopoulos D N 1997 Thessaloniki 91 field measurement campaign-II. Ozone formation in the Greater Thessaloniki Area; Atmos. Environ. 37 1115-1126.

Hales J 1996 Scientific background for AMS Policy Statement on Atmospheric Ozone; B. Am. Meteorol. Soc. 77 $1249-1253$.

Hsu K J 2007 Relationships between ten-year trends of tropospheric ozone and temperature over Taiwan; Sci. Total Environ. 374 135-142.

Isaksen I S A 1998 Tropospheric Ozone. Regional and Global Scale Interactions. NATO ASI Series (Dordrecht: Kluwer) 227425.

Jacob D J, Logan J A and Murti P P 1999 Effects of rising Asian emissions on surface ozone in the United States; Geophys. Res. Lett. 26 2175-2178.

Kalabokas P D, Viras L G, Bartzis J and Repapis C C 2000 Mediterranean rural ozone characteristics around the urban area of Athens; Atmos. Environ. 34 5199-5208.

Kinney P L and Ozkaynak H 1991 Associations of daily mortality and air pollution in Los Angeles County; Environ. Res. 54 99-120.

Klasinc L and Cvita T 1996 The photosmog problem in the Mediterranean region; Mar. Chem. 53 111-119.

Kondratyev K and Varotsos C 2000 Atmospheric Ozone Variability (Springer Praxis Publishing).

Kouvarakis G, Tsigaridis K, Kanakidou M and Mihalopoulos N 2000 Temporal variations of surface regional background ozone over Crete Island in the Southeast Mediterranean; J. Geophys. Res. 105 4399-4407.

Lalas D P, Tombrou-Tsella M, Petrakis M, Asimakopoulos D N and Helmis C G 1987 An experimental study of the vertical distribution of ozone over Athens; Atmos. Environ. 21 2681-2693.

Lelieveld J and Dentener F J 2000 What controls tropospheric ozone; J. Geophys. Res. 05(D3) 3531-3552. 
Li M, Mehrota K, Mohan C K and Ranka S 1990 Sunspot numbers forecasting using neural networks; Proc. IEEE Symp. Intell. Control. 1 524-529.

Liu S C, Kley D, McFarland M, Mahlman J D and Levy H 1980 On the origin of tropospheric ozone; J. Geophys. Res. 85 7546-7552.

McKee D J 1994 Tropospheric Ozone. CRC Press (Boca Raton, FL) 333.

Mihalakakou G, Santamouris M, Papanikolaou N, Cartalis C and Tsangrassoulis A 2004 Simulation of the urban heat island phenomenon in Mediterranean Climates; Pure Appl. Geophys. 161 429-451.

Nolle M, Ellul R, Heinrich G and Güsten H 2001 A long-term study of background ozone concentrations in the central Mediterranean - diurnal and seasonal variations on the island of Gozo, European Commission, Joint Research Centre, Institute for Environment and Sustainability, Climate Change Unit, A Changing Atmosphere 8th European symposium on the Physico-Chemical Behaviour of Atmospheric Pollutants, 17-20 September, Lingotto Conference Centre, Torino (Italy).

Oke T R 1987 Boundary Layer Climates (London and New York: Routledge) 2nd edition.

Oke T R, Johnson D G, Steyn D G and Watson I D 1991 Simulation of surface urban heat island under "ideal" conditions at night - Part 2: Diagnosis and causation; Bound.-Lay. Meteorol. 56 339-358.

Park H S 1986 Features of the heat island in Seoul and its surrounding cities; Atmos. Environ. 20 1859-1866.

Pont V and Fontan J 2000a Correlation between continental air mass and ozone concentrations; J. Geophys. Res. 105(D14) 17,699-17,707.

Pont V and Fontan J 2000b Local and regional contributions to photochemical atmospheric pollution in Southern France; Atmos. Environ. 34 5209-5223.

Rumelhart D E, Hinton G E and Williams R L 1986 Learning internal representations by error propagation, In: Parallel distributed processing (eds) D E Rumelhart and J L McClelland (Cambridge: MIT Press) 318-362.

Santamouris M, Mihalakakou G, Papanikolaou N and Asimakopoulos D N 1999 A neural network approach for modeling the heat island phenomenon in urban areas during the summer period; Geophys. Res. Lett. 26 $337-340$.

Sanz M J and Millán M M 1998 The dynamics of aged air masses and ozone in the Western Mediterranean: Relevance to forest ecosystems; Chemosphere 36 1089-1094.

Sonnemann G 1992 Ozon - Natürliche Schwankungen und anthropogene Einflüsse. Akademie Verlag GmbH, Berlin, Germany.

Staehelin J, Thudium J, Buehler R, Volz-Thomas A and Graber W 1994 Trends in surface ozone concentrations at Arosa (Switzerland); Atmos. Environ. 28 75-87.

Steinberger E H and Ganor E 1980 High ozone concentrations at night in Jerusalem and Tel-Aviv; Atmos. Environ. 14 221-225.

Tsani-Bazaca E, Glavas S and Güsten H 1988 Peroxyacetyl nitrate (PAN) concentrations in Athens, Greece; Atmos. Environ. 22 2283-2286.

USEPA 1986 Air quality criteria for ozone and other photochemical oxidants. Office of Research and Development, Washington, DC, USA 20460, EPA 600-84/020dF.

Valero F, Luna Y, Martin M L and Sancho P 1992 Tropospheric ozone concentrations related to atmospheric conditions at Izana BAPMoN weather station, Canary Islands; Nuovo Cimento C 15 159-172.

Volz A and Kley D 1988 Evaluation of the Montsouris series of ozone measurements made in the nineteenth century; Nature 332 240-242.

Walcek C J and Yuan H H 1999 Calculated influence of temperature-related factors on ozone formation rates in the lower troposphere; J. Appl. Meteorol. 34 1056-1069.

WMO (World Meteorological Organization) 2003 Scientific assessment of ozone Depletion, Global Ozone Research and Monitoring Project, Rep., vol. 47.

Ziomas I C 1998 The Mediterranean campaign of photochemical tracers-Transport and chemical evolution (Medcaphot-Trace): An outline; Atmos. Environ. 32 2045-2053.

Zurita E and Castro M 1983 A statistical analysis of mean hourly concentrations of surface ozone at Madrid (Spain); Atmos. Environ. 17 2213-2220. 